Check for updates

Cite this: RSC Adv., 2017, 7, 54485

Received 13th October 2017 Accepted 22nd November 2017

DOI: 10.1039/c7ra11283a

rsc.li/rsc-advances

\section{Electron transportation path build for superior photoelectrochemical performance of $\mathrm{Ag}_{3} \mathrm{PO}_{4} /$ $\mathrm{TiO}_{2} \dagger$}

\author{
Lianqing Yu, (D)* Jiandong He, (D) Chengxing Huang, Ming Li, Yaping Zhang, \\ Xiaoyan Zhou and Haifeng Zhu
}

\begin{abstract}
$\mathrm{TiO}_{2}$ is an attractive photoanode material with its large band gap, whilst its performance largely suffers from low efficiency on both charge separation and solar conversion. Herein, a self-organized $\mathrm{TiO}_{2}$ nanotube arrays (TNT) is prepared by anodized $\mathrm{Ti}$ foil in ethylene glycol electrolyte to ameliorate charge transmission ability. $\mathrm{Ag}_{3} \mathrm{PO}_{4}$ is further synthesized on TNT substrate by dipping method. HRTEM images results indicate $\mathrm{Ag}_{3} \mathrm{PO}_{4}$ nanoparticles are successfully deposited on the surfaces of TNT. Photoelectrochemical tests show the $\mathrm{Ag}_{3} \mathrm{PO}_{4} / \mathrm{TiO}_{2}$ heterojunction has a higher photocurrent density of $2.34 \mathrm{~mA} \mathrm{~cm}^{-2}$ at $\mathrm{OV}$ than that of pure TNT $\left(0.38 \mathrm{~mA} \mathrm{~cm}^{-2}\right)$. This is attributed to an $\mathrm{Ag}$ "pump" reduced on the interface of $\mathrm{Ag}_{3} \mathrm{PO}_{4} / \mathrm{TiO}_{2}$, therefore electron transportation path is built between $\mathrm{Ag}_{3} \mathrm{PO}_{4}$ and $\mathrm{TiO}_{2}$ leading to photogenerated electrons and holes effective separation. This high photocurrent density array films facilitates it a desirable photoelectrochemical material for water splitting.
\end{abstract}

\section{Introduction}

Photoelectrochemica (PEC) water splitting is recognized as one of the most promising strategies in solar energy conversion. Titanium dioxide $\left(\mathrm{TiO}_{2}\right)$ has been specifically selected out among various PEC materials since Honda-Fujishima first found the ability of $\mathrm{TiO}_{2}$ for photo-splitting water under ultraviolet light in $1972 .^{1}$ In 1976, Carey found that PCBs in $\mathrm{TiO}_{2}$ suspension solution successfully dechlorinated under UV irradiation. $^{2}$ In 1991, Graztel successfully developed a dyesensitized solar cell by using $\mathrm{TiO}_{2}$ nanoparticles. ${ }^{3}$ But $\mathrm{TiO}_{2}$ suffers from its poor charge separation and high charge transmission resistance., ${ }^{4,5}$ One dimensional (1-D) nanostructure allows a short diffusion length for holes in radial direction, whereas the long axial direction of the structure becomes the preferred electron channel that provides enough length of light attenuation as well. ${ }^{6,7}$ Besides these above, 1-D nanostructures also provide excellent photovoltaic, photocatalytic, and PEC properties relative to random-shaped particles. ${ }^{8-12}$ Therefore, the 1-D self-organized $\mathrm{TiO}_{2}$ nanotube array (TNT) is expected to design. In 2001, Grimes and co-workers successfully prepared TNT by anodization in hydrofluoric acid electrolyte. ${ }^{13}$ Further, Macak synthesized TNT by anodizing in glycerol electrolyte containing $0.5 \% \mathrm{NH}_{4} \mathrm{~F}$, the morphology more smooth than that obtained in aqueous electrolyte, and the length of nanotube

College of Science, China University of Petroleum, Qingdao 266580, China. E-mail: iyy2000@163.com

$\dagger$ Electronic supplementary information (ESI) available. See DOI: 10.1039/c7ra11283a reached above $10 \mu \mathrm{m} .{ }^{14}$ Also, TNT exhibits more attractive PEC performance and larger specific surface area than $\mathrm{TiO}_{2}$ nanoparticles or nanosheets. ${ }^{\mathbf{1 5 , 1 6}}$ However, band gap of $\mathrm{TiO}_{2}$ at 3.0$3.2 \mathrm{eV}$ can only absorb ultraviolet light corresponding for $5 \%$ of sunlight, which means the solar utilization efficiency is less than satisfactory.

$\mathrm{Ag}_{3} \mathrm{PO}_{4}$ a n-type semiconductor can absorb visible light wavelengths less than $520 \mathrm{~nm}$ (indirect band gap of $2.4 \mathrm{eV}$ ), and the quantum yield reaches more than $90 \%$, which aroused attention of many researchers $;^{17-19}$ but its conduction band (CB) is at $0.45 \mathrm{~V} v s$. NHE, $\mathrm{so}^{+}{ }^{+}$of $\mathrm{Ag}_{3} \mathrm{PO}_{4}$ will be easily reduced to elemental $\mathrm{Ag}$ under visible light irradiation. ${ }^{\mathbf{1 0 2 0 - 2 6}}$ Wang et al. studied $\mathrm{Ag}_{3} \mathrm{PO}_{4} / \mathrm{AgBr} / \mathrm{Ag}$ degradation of organic matter, due to better stability of $\mathrm{AgBr}$ and plasma effect of $\mathrm{Ag}$ nanoparticles, which improved $\mathrm{Ag}_{3} \mathrm{PO}_{4}$ stability and photocatalytic capacity. ${ }^{27}$ Teng found that $\mathrm{Ag} / \mathrm{Ag}_{3} \mathrm{PO}_{4} / \mathrm{TiO}_{2}$ can photodegrade chlorophenol efficiently, and $\mathrm{Ag}$ nanoparticles can effectively prevent the occurrence of $\mathrm{Ag}_{3} \mathrm{PO}_{4}$ light corrosion, and photocurrent density at $0.28 \mathrm{~mA} \mathrm{~cm}{ }^{-2} .^{28} \mathrm{Xu}$ et al. reported $\mathrm{Ag}_{3} \mathrm{PO}_{4} / \mathrm{TiO}_{2} / \mathrm{Fe}_{3} \mathrm{O}_{4}$ photodegraded benzene sulfonate and had a great bactericidal effect. $^{29}$ Photodegradation properties on $\mathrm{Ag}_{3} \mathrm{PO}_{4}$ or its composites can be found in many research, but seldom on PEC properties, which is closely relative to photo-water-splitting. Moreover, all of works is not enough to achieve high performance because electrons randomly flow after the electron-hole separation resulting in fast electron-hole recombination.

In this study, $\mathrm{Ag}_{3} \mathrm{PO}_{4}$ nanoparticles were chemically deposited on 1-D TNT. A heterojunction of $\mathrm{Ag}_{3} \mathrm{PO}_{4} / \mathrm{TiO}_{2}$ was formed and linear sweep voltammetry test showed photocurrent was about 6 times bigger than pure TNT and the band flat potentials 
of $\mathrm{Ag}_{3} \mathrm{PO}_{4} / \mathrm{TiO}_{2}$ positively shifted, which meant solar absorption range of $\mathrm{TiO}_{2}$ was significantly broadened. Ag was also synthesized on the interface between $\mathrm{Ag}_{3} \mathrm{PO}_{4}$ and $\mathrm{TiO}_{2}$ due to light illumination, which formed an efficient system for separation of photo-generated charges and improvement of PEC properties.

\section{Experimental}

\subsection{Sample $\mathrm{Ag}_{3} \mathrm{PO}_{4} / \mathrm{TiO}_{2}$ preparation}

Ti foil of $1 \mathrm{~cm}^{2}$ was provided with anodization in ethylene glycol electrolyte containing $4 \mathrm{wt} \% \mathrm{H}_{2} \mathrm{O}$ and $0.25 \mathrm{wt} \% \mathrm{NH}_{4} \mathrm{~F}$ for $1 \mathrm{~h}$ under constant potential $(50 \mathrm{~V})$ at room temperature. ${ }^{\mathbf{1 4 , 3 0}}$ The samples were washed with distilled water and dried at $60{ }^{\circ} \mathrm{C}$. The as-prepared $\mathrm{TiO}_{2}$ was thermally treated at $450{ }^{\circ} \mathrm{C}$ for $2 \mathrm{~h}$ under atmospheric conditions.

$\mathrm{Ag}_{3} \mathrm{PO}_{4}$ nanoparticles were deposited into the crystallized $\mathrm{TiO}_{2}$ nanotubes by sequential chemical bath deposition method. Typically, the sample was successively immersed in four different beakers for 3 minutes in each beaker. One beaker contained $5 \mathrm{mM} \mathrm{AgNO}$ aqueous solution, another contained $5 \mathrm{mM} \mathrm{NaH}{ }_{2} \mathrm{PO}_{4}$, and the other two contained distilled water to rinse the samples from the excess of each precursor solution. Such an immersion cycle was repeated several times, typically between 2 and 8 cycles.

\subsection{Characterization}

The surface morphology was observed through a field-emission scanning electron microscope (Hitachi S-4800, Japan). Transmission electron microscopy (TEM) images were taken with
JEOL JEM-2100 transmission electron microscope at $200 \mathrm{kV}$. The absorbance was measured with UV-vis spectrophotometer (Hitachi U-3900, Japan). The elemental chemical status was measured by X-ray photoelectron spectroscopy (Thermo ESCA$\mathrm{LAB} 250 \mathrm{Xi}$ ), equipped with $\mathrm{Al} \mathrm{K} \alpha$ radiation. All energies were calibrated to spurious carbon at $284.8 \mathrm{eV}$.

The PEC properties of samples were investigated by a threeelectrode configuration electrochemical workstation (CHI $760 \mathrm{E}$ ), employing the samples, $\mathrm{Ag} / \mathrm{AgCl}$ and Pt mesh as working, reference and counter electrode, respectively (Fig. S4†). The supporting electrolyte used was $1 \mathrm{M} \mathrm{KOH}(\mathrm{pH}=14)$ aqueous solution. Mott-Schottky plots were measured at $1000 \mathrm{~Hz}$. Electrochemical impedance spectroscopic (EIS) measurements were performed between $10^{5} \mathrm{~Hz}$ and $10^{-2} \mathrm{~Hz}$ dark. The working electrode was illuminated with a $300 \mathrm{~W}$ xenon lamp. The photocurrent was recorded concurrently with the light switching on and off without applied voltage.

\section{Results and discussion}

\subsection{Electron transportation analysis}

After deposited $\mathrm{Ag}_{3} \mathrm{PO}_{4}$, a heterojunction of $\mathrm{Ag}_{3} \mathrm{PO}_{4} / \mathrm{TiO}_{2}$ first formed and promoted separation of the photogenerated carriers. ${ }^{25,31,32}$ Additionally, $\mathrm{Ag}^{+}$of $\mathrm{Ag}_{3} \mathrm{PO}_{4}$ was proved photoreduced and decomposed to weakly active $\mathrm{Ag}$ under photoillumination, ${ }^{31-35}$ which could obviously enhance visible light absorbance above $700 \mathrm{~nm}$ (Fig. 1c) and accelerate photogenerated carrier separation due to its surface plasma resonance (SPR). ${ }^{28,36}$ As reported by many researchers, SPR in Ag can
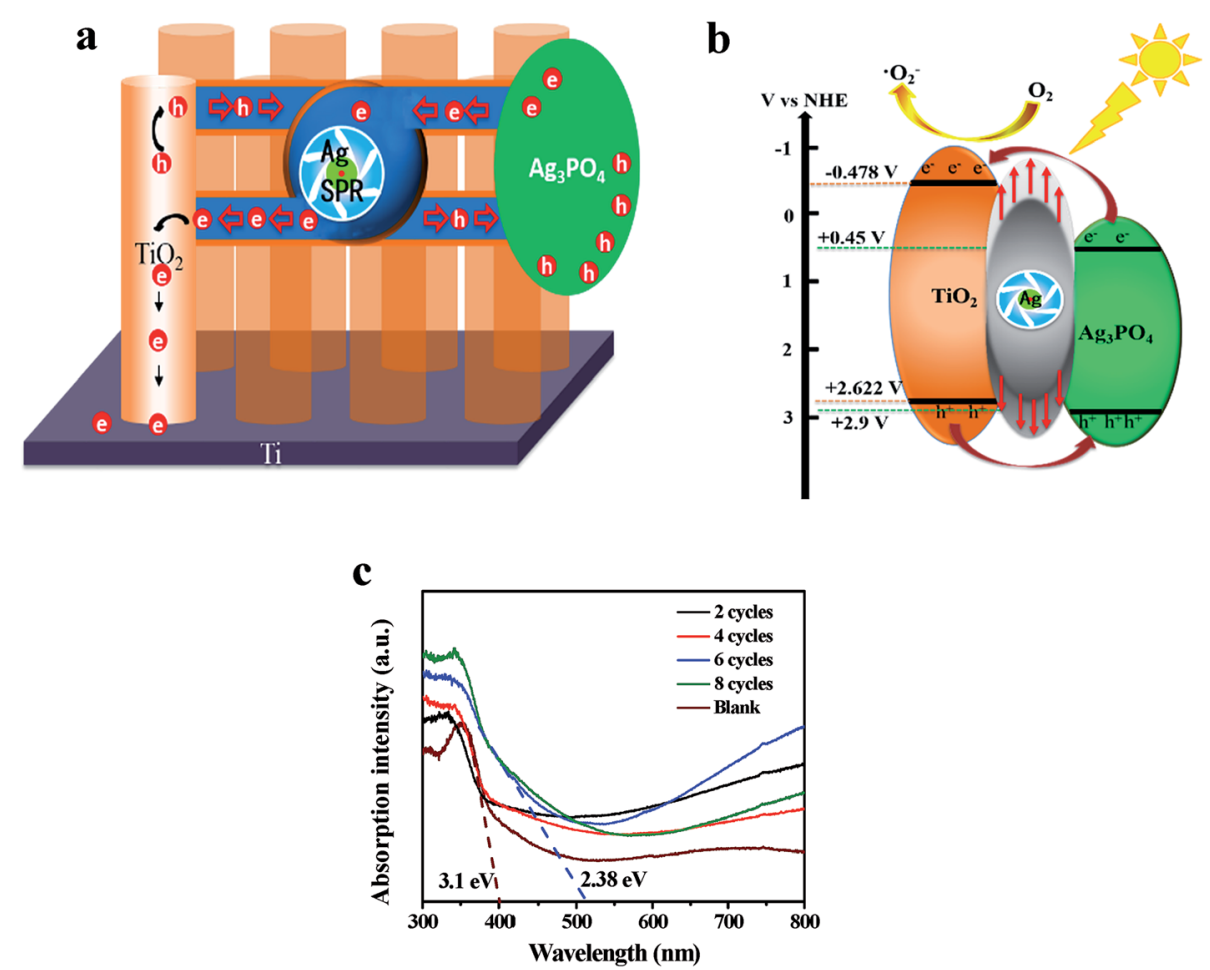

Fig. 1 Schematic diagram of bidirectional photo-induced electron transportation (a), photogenerated electron-hole pairs separation process (b) and UV-vis spectra (c). 

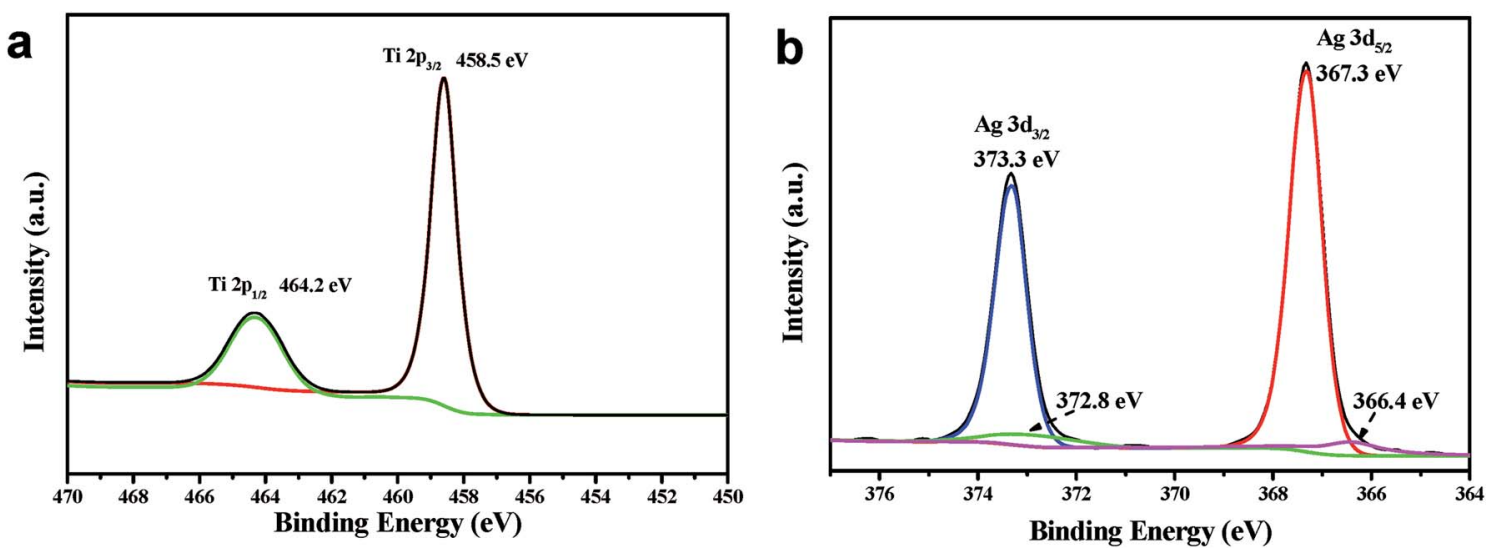

Fig. 2 High resolution XPS spectra of (a) Ti $2 \mathrm{p}$ and (b) $\mathrm{Ag} 3 \mathrm{~d}$ of $\mathrm{Ag}_{3} \mathrm{PO}_{4} / \mathrm{TiO}_{2}$.

be directly excited under visible light illumination to generate and inject hot carriers into the CB of semiconductors. ${ }^{37,38}$ This role is just like a "pump" (Fig. 1a and b), electrons in $\mathrm{Ag}_{3} \mathrm{PO}_{4}$ are absorbed by Ag and then "pumped" into higher energy level, the $\mathrm{CB}$ of $\mathrm{TiO}_{2}$, due to lower conductivity of $\mathrm{Ag}_{3} \mathrm{PO}_{4}$ and SPR of $\mathrm{Ag}$ which assisted electrons to get over the barrier of $\mathrm{Ag}_{3} \mathrm{PO}_{4} / \mathrm{TiO}_{2}$ junction. Then electrons transported from the $\mathrm{CB}$ of $\mathrm{TiO}_{2}$ to $\mathrm{Ti}$ base along 1-D electron channel of TNT. Equally, holes were injected from the valence band $(\mathrm{VB})$ of $\mathrm{TiO}_{2}$ into the $\mathrm{VB}$ of $\mathrm{Ag}_{3} \mathrm{PO}_{4}$, and then participated in oxidation reaction. The transfer route of electron can be $E_{\mathrm{CB}}\left(\mathrm{Ag}_{3} \mathrm{PO}_{4}\right) \rightarrow E_{\mathrm{f}}(\mathrm{Ag}) \rightarrow$ $E_{\mathrm{CB}}\left(\mathrm{TiO}_{2}\right)$. If without the SPR of $\mathrm{Ag}$, charges transportation route are shown in Fig. S4, $\dagger$ the light induced electrons transported from higher conductor band $\left(-0.612 \mathrm{~V} v s\right.$. NHE) of $\mathrm{TiO}_{2}$ to lower conductor band $\left(+0.45 \mathrm{~V} v\right.$ s. NHE) of $\mathrm{Ag}_{3} \mathrm{PO}_{4}$, and the holes were accumulated in the valence band of $\mathrm{TiO}_{2}$, which is inconsistent with experimental results of electron transportation from $\mathrm{TiO}_{2}$ to Ti foil.

\subsection{XPS analysis}

$\mathrm{Ag}_{3} \mathrm{PO}_{4} / \mathrm{TiO}_{2}$ sample was examined by X-ray photoelectron spectroscopy (XPS), and the results are shown in Fig. 2. The binding energies of the XPS spectra were calibrated by C $1 \mathrm{~s}$ $(284.8 \mathrm{eV})$. The carbon peak is due to the adventitious hydrocarbon from the XPS instrument itself (Fig. S2 $\dagger$ ). In Fig. 2a, the characteristic peak at $458.5 \mathrm{eV}$ and $464.2 \mathrm{eV}$ assigned to $\mathrm{Ti}^{4+}$ in
$\mathrm{TiO}_{2}$ are depicted. ${ }^{39}$ Two binds at 367.7 and $373.7 \mathrm{eV}$, are ascribed to $\mathrm{Ag} 3 \mathrm{~d}_{5 / 2}$ and $\mathrm{Ag} 3 \mathrm{~d}_{3 / 2}$ bonding energies in Fig. $2 \mathrm{~b}$. These bands could be further deconvoluted into two peaks, respectively, at $366.4,367.3 \mathrm{eV}$ and $372.8,373.7 \mathrm{eV}$, where the bands at 366.4 and $372.8 \mathrm{eV}$ are ascribed to the $\mathrm{Ag}^{+}$of $\mathrm{Ag}_{3} \mathrm{PO}_{4}$, and those at 367.3 and $373.7 \mathrm{eV}$ are attributed to the metallic $\mathrm{Ag}^{0}$. As some papers have reported, ${ }^{40,41}$ these results verify the existence of metallic $\mathrm{Ag}^{0}$ on $\mathrm{Ag}_{3} \mathrm{PO}_{4} / \mathrm{TiO}_{2}$ photocatalysts after the reaction.

\subsection{Morphology characterization}

Diameter of the self-organized pure TNT prepared by anodizing method is about 60 to $90 \mathrm{~nm}$ (Fig. 3a and b). Fig. 3b showed SEM images of the sample for 4 cycles deposited $\mathrm{Ag}_{3} \mathrm{PO}_{4}$ on TNT, and the nanoparticles of $\mathrm{Ag}_{3} \mathrm{PO}_{4}$ covered the surface with a diameter of about $10 \mathrm{~nm}$. Also, some particles with a diameter of 40 to $50 \mathrm{~nm}$ were formed because of severe agglomeration for 8 cycles, shown in Fig. S3. $\dagger$ Illustration of EDS indicated that the atomic proportion of $\mathrm{Ag}$ and $\mathrm{P}$ is 2.44 to 1, close to stoichiometric ratio of 3 to 1 (Fig. 3c).

TEM images of the sample for 4 cycles deposited $\mathrm{Ag}_{3} \mathrm{PO}_{4}$ on TNT were shown in Fig. $4 \mathrm{a}$ and b. $\mathrm{Ag}_{3} \mathrm{PO}_{4}$ nanoparticles located at both surface TNT and inside of nanotubes at a diameter of 10-20 nm. To further confirm the existence of $\mathrm{Ag}_{3} \mathrm{PO}_{4}, \mathrm{HRTEM}$ (Fig. 4c) showed the lattice fringe of $0.35 \mathrm{~nm}$ was consistent with
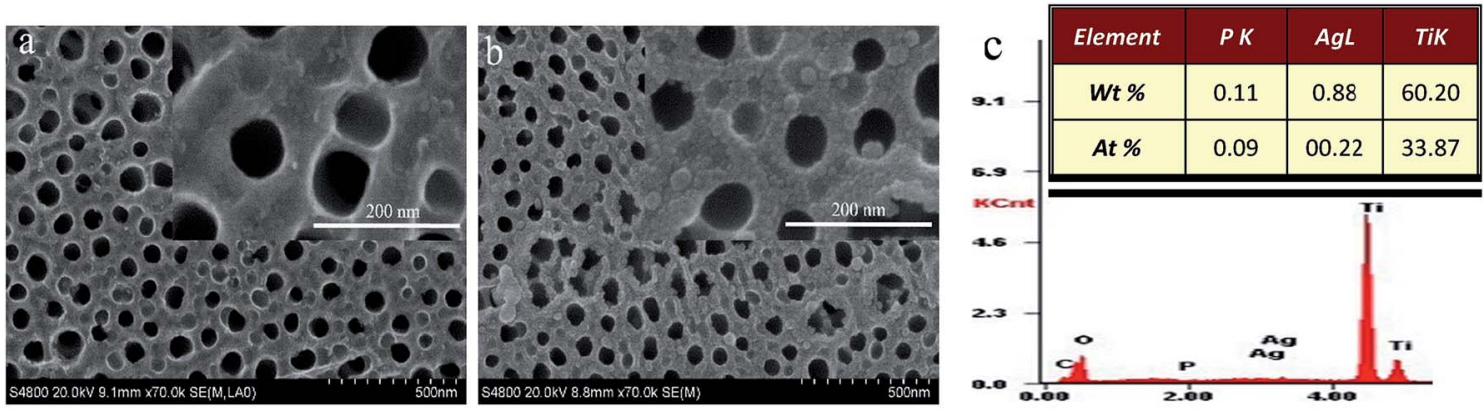

Fig. 3 SEM images of pure $\mathrm{TiO}_{2}$ (a), $\mathrm{Ag}_{3} \mathrm{PO}_{4} / \mathrm{TiO}_{2} 4$ cycles (b), insert is partial enlarged view of (a) and (b), EDS of 4 cycles (c). 

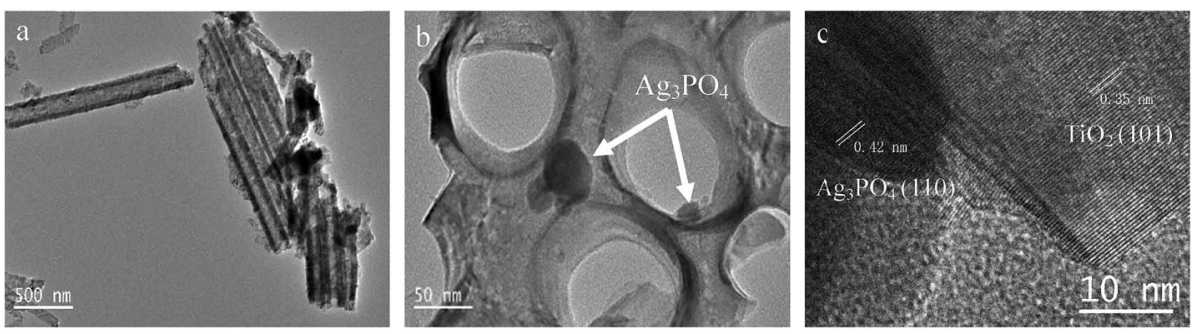

Fig. 4 TEM (a, b) and HRTEM (c) images of $\mathrm{Ag}_{3} \mathrm{PO}_{4} / \mathrm{TiO}_{2}, 4$ cycles.

(101) facet of anatase $\mathrm{TiO}_{2}$, while the lattice fringe of $0.42 \mathrm{~nm}$ was assigned to the (110) facet of $\mathrm{Ag}_{3} \mathrm{PO}_{4}$.

\subsection{Photoelectrochemical properties}

Under scanning potential between $-0.9 \mathrm{~V}$ to $0.3 \mathrm{~V} v$ s. $\mathrm{Ag} / \mathrm{AgCl}$, the current density of TNT deposited $\mathrm{Ag}_{3} \mathrm{PO}_{4}$ were bigger than that of the pure TNT (Fig. 5a), only $0.387 \mathrm{~mA} \mathrm{~cm}^{-2}$ at $0 \mathrm{~V} v \mathrm{~s}$. Ag/ $\mathrm{AgCl}$, whereas the current density of 4 cycles deposition was almost 5 times higher, reached to $2.340 \mathrm{~mA} \mathrm{~cm}{ }^{-2}$. It reported that maximum photocurrent of $\mathrm{Ag}_{3} \mathrm{PO}_{4} / \mathrm{TiO}_{2}$ nanowire array heterostructure photoelectrodes was about $0.7 \mathrm{~mA} \mathrm{~cm}{ }^{-2}$ at an applied bias $0.23 \mathrm{~V} v s$. $\mathrm{Ag} / \mathrm{AgCl}{ }^{42}$ The improvement of photocurrent could be ascribed to $\mathrm{Ag}$ "pump", preferred electron transportation direction along TNT and large absorption spectrum of $\mathrm{Ag}_{3} \mathrm{PO}_{4} \cdot{ }^{29,43} \mathrm{UV}$-vis spectra (Fig. 1c) proved the band gap of pure TNT and $\mathrm{Ag}_{3} \mathrm{PO}_{4}$ at $3.1 \mathrm{eV}$ and $2.38 \mathrm{eV}$, respectively. And the recombination of photogenerated charge carriers was significantly reduced in the heterojunction (Fig. S1b $\dagger$ ). Under intermittent light irradiation, time-dependent photocurrent generation is presented in Fig. $5 \mathrm{~b}$. The photocurrents respond exactly to the presence of solar light was interrupted every $50 \mathrm{~s}$ (light on/off) under $0 \mathrm{~V} v s$. $\mathrm{Ag} / \mathrm{AgCl}$, and the steady state behavior of each photoanode follows the same trend as that of the $I-V$ curves (Fig. 5a). Furthermore, the loading amounts of $\mathrm{Ag}_{3} \mathrm{PO}_{4}$ on TNT increase with the increasing of cycle time (Fig. $3 \mathrm{c}$ and S3ct). Whatever $I-V$ curves or $I-t$ curves showed photocurrent increased initially and then decreased with increase loading amount of $\mathrm{Ag}_{3} \mathrm{PO}_{4}$. Therefore appropriate loading amounts of $\mathrm{Ag}_{3} \mathrm{PO}_{4}$ is fatal to enhance PEC performance of TNT. In addition, there are no appreciable dark currents, demonstrating the photochemical stability of all of photoanodes in the alkaline solution. The steady-state photocurrents do not show any significant degradation with time. ${ }^{44}$

Fig. 6a represented Nyquist diagrams from electrochemical impedance spectroscopy (EIS) for samples tested in dark. The equivalent circuit for this cell system was depicted in inset of Fig. $6 \mathrm{a} . R_{\mathrm{b}}$ was the bulk resistance of the electrolyte. $C_{\mathrm{sc}}$ and $R_{\mathrm{sc}}$ were the capacitance and the resistance of the solid-state interfacial layer which was formed at the highly charged state due to the passivation reaction between the electrolyte and the surface of the electrode. $C_{\mathrm{dl}}$ and $R_{\mathrm{ct}}$ were the double layer capacitance and the charge transfer resistance. $W$ was the Warburg resistance result from the diffusion resistance of redox couple.

The Mott-Schottky plots of $\mathrm{Ag}_{3} \mathrm{PO}_{4} / \mathrm{TiO}_{2}$ are used to analyze the flat band potential and carrier concentrations of semiconductor (Fig. 6b). Under the applied voltage, the Fermi level can be changed and bended the energy band, and flat band potential $V_{\mathrm{fb}}$ refers the applied potential which makes the inner electric field intensity of semiconductor approach zero. The carrier concentrations of semiconductor $N_{\mathrm{D}}$ and the slope of linear part of Mott-Schottky plots have the relation as follow:

$$
N_{\mathrm{D}}=\frac{2}{e \varepsilon \varepsilon_{0} m}
$$

where, $e$ is the elementary charge $\left(1.602 \times 10^{-19} \mathrm{C}\right), \varepsilon$ is the dielectric constant of sample and the dielectric constant of anatase is $48, \varepsilon_{0}$ is the vacuum dielectric constant $(8.854 \times$
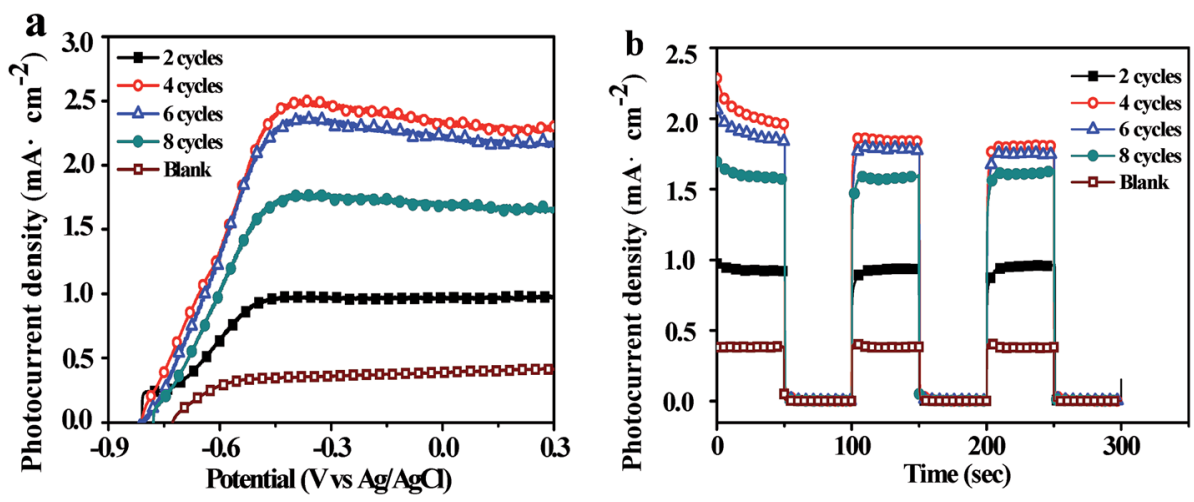

Fig. $5 \quad \mathrm{Ag}_{3} \mathrm{PO}_{4} / \mathrm{TiO}_{2}$ composites linear sweeps voltammetry (a), i-t curve (b), UV-vis spectra. 

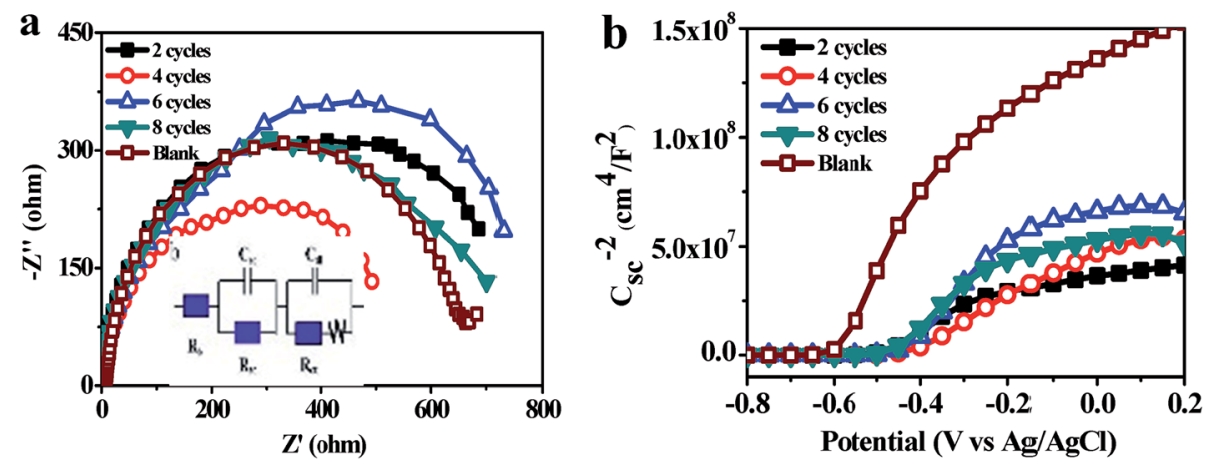

Fig. $6 \quad \mathrm{Ag}_{3} \mathrm{PO}_{4} / \mathrm{TiO}_{2}$ Nyquist diagrams (a), insert is equivalent circuit fitting the EIS and Mott-Schottky plots (b).

$\left.10^{-14} \mathrm{~F} \mathrm{~cm}^{-1}\right), m$ is the slope of the linear part of Mott-Schottky plots. The flat band potential $V_{\mathrm{fb}}, C_{\mathrm{SC}}$ and carrier concentrations $N_{\mathrm{D}}$ have a relationship, below:

$$
C_{\mathrm{SC}}^{-2}=\left(\frac{2}{\varepsilon_{0} \varepsilon e N_{\mathrm{D}}}\right)\left(V-V_{\mathrm{fb}}-\frac{k_{\mathrm{B}} T}{e}\right)
$$

where, $C_{\mathrm{SC}}$ is the space charge capacitance, $\varepsilon_{0}, \varepsilon$ and $e$ are constant, $N_{\mathrm{D}}$ is carrier concentrations, $V$ and $V_{\mathrm{fb}}$ is respectively the applied potential and the flat band potential ( $v s$. the potential of the reference electrode), $\left(k_{\mathrm{B}} T\right) / e$ is $25.8 \mathrm{mV}$ at room temperature.

The parameters obtained from EIS and Mott-Schottky plots are shown in Table 1 . The charge transfer resistances $R_{\mathrm{ct}}$ of 4 cycles deposition $\mathrm{Ag}_{3} \mathrm{PO}_{4}$ minimal only $404.7 \mathrm{ohm} \mathrm{cm} \mathrm{cm}^{-2}$, since the carrier concentration $N_{\mathrm{D}}$ of it was 2.6 times higher than that of the pure $\mathrm{TiO}_{2}$ about $4.85 \times 10^{22} \mathrm{~cm}^{-3}$. Moreover, the carrier concentration of $\mathrm{Ag}_{3} \mathrm{PO}_{4} / \mathrm{TiO}_{2}$ samples was obviously higher than that of the pure $\mathrm{TiO}_{2}$. And valence bands of two semiconductors were very close ${ }^{29,33,43,45,46}$ which inferred the heterojunction formed by depositing $\mathrm{Ag}_{3} \mathrm{PO}_{4}$ nanoparticles on TNT (Fig. 1b). Potentials of both conduction band $(-0.612 \mathrm{~V} v s$. NHE) and valence band $(+2.588 \mathrm{~V} v s$. NHE $)$ of $\mathrm{TiO}_{2}$ are more negative than those of $\mathrm{Ag}_{3} \mathrm{PO}_{4}$ (conduction band potential: $+0.45 \mathrm{~V}$ vs. $\mathrm{NHE}$, valence band potential: $+2.9 \mathrm{~V} v s$. NHE). ${ }^{33}$ It benefits for transfer of photogenerated carriers and separation of photogenerated electron-hole pairs, also increases the carrier concentrations. The flat band potential $\left(V_{\mathrm{fb}}\right)$ is close to the conduction band which makes the curving band of space charge layer straight. The $V_{\mathrm{fb}}$ of TNT was $-0.612 \mathrm{~V}$, after deposition $\mathrm{Ag}_{3} \mathrm{PO}_{4}$ of 4 cycles $V_{\mathrm{fb}}$ lowed to $-0.410 \mathrm{~V}$. The reason for lower $V_{\mathrm{fb}}$ was the photogenerated electrons were "pumped" into $\mathrm{CB}$ of $\mathrm{TiO}_{2}$ by SPR of Ag. It

Table 1 Physics parameters of $\mathrm{Ag}_{3} \mathrm{PO}_{4} / \mathrm{TiO}_{2}$

\begin{tabular}{llll}
\hline Sample & $R_{\mathrm{ct}}\left(\mathrm{ohm} \mathrm{cm}^{-2}\right)$ & $N_{\mathrm{D}}\left(\mathrm{cm}^{-3}\right)$ & $V_{\mathrm{fb}}(\mathrm{V})$ \\
\hline 2 cycles & 667.5 & $4.40 \times 10^{22}$ & -0.478 \\
4 cycles & 404.7 & $4.85 \times 10^{22}$ & -0.410 \\
6 cycles & 698.8 & $2.42 \times 10^{22}$ & -0.433 \\
8 cycles & 621.4 & $3.16 \times 10^{22}$ & -0.468 \\
Blank & 594.8 & $1.35 \times 10^{22}$ & -0.612
\end{tabular}

meant the range of absorption spectrum broaden and photocatalytic properties enhancement. As shown in Fig. 1c, the absorbance of $\mathrm{Ag}_{3} \mathrm{PO}_{4} / \mathrm{TiO}_{2}$ was significantly increased than pure $\mathrm{TiO}_{2}$, implying $\mathrm{Ag}_{3} \mathrm{PO}_{4}$ is a very promising material for building fast electron transportation path to improve PEC performance of $\mathrm{TiO}_{2}$.

\section{Conclusion}

A preferred electron transportation path was designed to improve the photoelectrocatalytic activity through deposition $\mathrm{Ag}_{3} \mathrm{PO}_{4}$ nanoparticles to the self-organized $\mathrm{TiO}_{2}$ nanotube arrays. $\mathrm{Ag}_{3} \mathrm{PO}_{4} / \mathrm{TiO}_{2}$ effectively reduced the recombination of photogenerated electron-hole pairs due to unique 1-D nanostructure, as well as SPR of photoreduced $\mathrm{Ag}$ from $\mathrm{Ag}_{3} \mathrm{PO}_{4}$. The charge carrier concentration of $\mathrm{Ag}_{3} \mathrm{PO}_{4} / \mathrm{TiO}_{2}$ increased 2.6 times than that of pure TNT. The photocurrents of $\mathrm{Ag}_{3} \mathrm{PO}_{4} / \mathrm{TiO}_{2}$ were significantly improved by 5 times. Therefore, fabrication of $\mathrm{Ag}_{3} \mathrm{PO}_{4} / \mathrm{TiO}_{2}$ nanotube arrays is a highly efficient method to build a noteworthy photoelectrode for PEC water splitting.

\section{Conflicts of interest}

There are no conflicts to declare.

\section{Acknowledgements}

The financial support for this study by National Natural Science Foundation of China (No. 21476262). The Technology Development Plan of Qingdao (No. 14-2-4-108-jch). Research Funds for the Central Universities (No. 15CX05032A) are gratefully acknowledged.

\section{References}

1 A. Fujishima and K. Honda, Nature, 1972, 238, 37-38.

2 J. H. Carey, J. Lawrence and H. M. Tosine, Bull. Environ. Contam. Toxicol., 1976, 16, 697-701.

3 B. O'Regan and M. Gratzel, Nature, 1991, 353, 737-740.

4 K. Park, Q. Zhang, D. Myers and G. Cao, ACS Appl. Mater. Interfaces, 2013, 5, 1044-1052. 
5 J. Low, B. Cheng and J. Yu, Appl. Surf. Sci., 2017, 392, 658686.

6 W.-T. Sun, Y. Yu, H.-Y. Pan, X.-F. Gao, Q. Chen and L.-M. Peng, J. Am. Chem. Soc., 2008, 130, 1124-1125.

7 X. Feng, K. Shankar, O. K. Varghese, M. Paulose, T. J. Latempa and C. A. Grimes, Nano Lett., 2008, 8, 37813786.

8 H. Xiong, M. D. Slater, M. Balasubramanian, C. S. Johnson and T. Rajh, J. Phys. Chem. Lett., 2011, 2, 2560-2565.

9 B. Liu and E. S. Aydil, J. Am. Chem. Soc., 2009, 131, 39853990.

10 Q. Liang, Y. Shi, W. Ma, Z. Li and X. Yang, Phys. Chem. Chem. Phys., 2012, 14, 15657-15665.

11 H. Cheng-Xing, Y. Lian-Qing, Z. Ya-Ping, D. Kai-Tuo and H. Lan-Zhong, J. Inorg. Mater., 2016, 31, 1237-1241.

12 L. Yu, Y. Zhang, Q. Zhi, Q. Wang, F. Gittleson, J. Li and A. D. Taylor, Sens. Actuators, B, 2015, 211, 111-115.

13 D. Gong, C. A. Grimes, O. K. Varghese, et al., J. Mater. Res., 2001, 16, 3331-3334.

14 J. M. Macak, H. Tsuchiya, L. Taveira, A. Ghicov and P. Schmuki, J. Biomed. Mater. Res., Part A, 2005, 75, 928-933.

15 Z. Zhang and P. Wang, Energy Environ. Sci., 2012, 5, 65066512.

16 K. Lee, A. Mazare and P. Schmuki, Chem. Rev., 2014, 114, 9385-9454.

17 C. Feng, Y. Pang, Y. Wang, M. Sun, C. Zhang, L. Zhang, Y. Zhou and D. Li, Appl. Surf. Sci., 2016, 376, 188-198.

18 L. Ma, H. Han, L. Pan, M. Tahir, L. Wang, X. Zhang and J.-J. Zou, RSC Adv., 2016, 6, 63984-63990.

19 X. Yang, H. Cui, Y. Li, J. Qin, R. Zhang and H. Tang, ACS Catal., 2013, 3, 363-369.

20 N. Umezawa, O. Y. Shuxin and J. H. Ye, Phys. Rev. B: Condens. Matter Mater. Phys., 2011, 83, 8.

21 Y. Bi, H. Hu, S. Ouyang, Z. Jiao, G. Lu and J. Ye, J. Mater. Chem., 2012, 22, 14847-14850.

22 Y. Bi, H. Hu, S. Ouyang, G. Lu, J. Cao and J. Ye, Chem. Commun., 2012, 48, 3748-3750.

23 H. Hu, Z. Jiao, T. Wang, J. Ye, G. Lu and Y. Bi, J. Mater. Chem. A, 2013, 1, 10612-10616.

24 H. Hu, Z. Jiao, H. Yu, G. Lu, J. Ye and Y. Bi, J. Mater. Chem. A, 2013, 1, 2387-2390.

25 C. Cui, Y. Qiu, H. Hu, N. Ma, S. Li, L. Xu, L. Chaorong, J. Xu and T. Weihua, RSC Adv., 2016, 6, 43697-43706.

26 J. Li, X. Ji, X. Li, X. Hu, Y. Sun, J. Ma and G. Qiao, Appl. Surf. Sci., 2016, 372, 30-35.
27 W.-S. Wang, H. Du, R.-X. Wang, T. Wen and A.-W. Xu, Nanoscale, 2013, 5, 3315-3321.

28 W. Teng, X. Li, Q. Zhao and G. Chen, J. Mater. Chem. A, 2013, 1, 9060-9068.

29 J.-W. Xu, Z.-D. Gao, K. Han, Y. Liu and Y.-Y. Song, ACS Appl. Mater. Interfaces, 2014, 6, 15122-15131.

30 F.-Q. Xiong, X. Wei, X. Zheng, D. Zhong, W.-H. Zhang and C. Li, J. Mater. Chem. A, 2014, 2, 4510-4513.

31 X. Yang, J. Qin, Y. Jiang, K. Chen, X. Yan, D. Zhang, R. Li and H. Tang, Appl. Catal., B, 2015, 166-167, 231-240.

32 X. Yang, J. Qin, Y. Jiang, R. Li, Y. Li and H. Tang, RSC Adv., 2014, 4, 18627-18636.

33 W. Yao, B. Zhang, C. Huang, C. Ma, X. Song and Q. Xu, J. Mater. Chem., 2012, 22, 4050-4055.

34 H. Tang, Y. Fu, S. Chang, S. Xie and G. Tang, Chin. J. Catal., 2017, 38, 337-347.

35 X. Yang, Z. Chen, J. Xu, H. Tang, K. Chen and Y. Jiang, ACS Appl. Mater. Interfaces, 2015, 7, 15285-15293.

36 D. Wang, L. Li, Q. Luo, J. An, X. Li, R. Yin and M. Zhao, Appl. Surf. Sci., 2014, 321, 439-446.

37 S. Bai, X. Li, Q. Kong, R. Long, C. Wang, J. Jiang and Y. Xiong, Adv. Mater., 2015, 27, 3444-3452.

38 X. Yang, H. Tang, J. Xu, M. Antonietti and M. Shalom, ChemSusChem, 2015, 8, 1350-1358.

39 C. Wagner, W. Riggs, L. Davis, J. Moulder and G. Muilenberg, Handbook of X-ray Photoelectron Spectroscopy, Perkin-Elmer Corp, 1979.

40 P. Wang, B. Huang, Z. Lou, X. Zhang, X. Qin, Y. Dai, Z. Zheng and X. Wang, Chem.-Eur. J., 2010, 16, 538-544.

41 P. Wang, B. Huang, Q. Zhang, X. Zhang, X. Qin, Y. Dai, J. Zhan, J. Yu, H. Liu and Z. Lou, Chem.-Eur. J., 2010, 16, 10042-10047.

42 B. Jin, X. Zhou, J. Luo, X. Xu, L. Ma, D. Huang, Z. Shao and Z. Luo, RSC Adv., 2015, 5, 48118-48123.

43 B. Lu, N. Ma, Y. Wang, Y. Qiu, H. Hu, J. Zhao, D. Liang, S. Xu, X. Li, Z. Zhu and C. Cui, J. Alloys Compd., 2015, 630, 163-171.

44 J. S. Jang, C. W. Ahn, S. S. Won, J. H. Kim, W. Choi, B.-S. Lee, J.-H. Yoon, H. G. Kim and J. S. Lee, J. Phys. Chem. C, 2017, 121, 15063-15070.

45 S. B. Rawal, S. D. Sung and W. I. Lee, Catal. Commun., 2012, 17, 131-135.

46 L. Zhang, H. Zhang, H. Huang, Y. Liu and Z. Kang, New J. Chem., 2012, 36, 1541-1544. 